\title{
1 The Spiritual Journey of Jesus Christ
}

\author{
2 Martin L. Nelwan
}

3 Department of Animal Science - Other

4 Nelwan Institution for Human Resource Development

$5 \quad$ Jl. A. Yani No. 24, Palu, Indonesia

6 Email: mlnelwan2@gmail.com

7 Abstract: The gospel does not introduce a new Lord. There is no other Lord in Christianity, except Christ. 8 God in the Old Testament is the same as God in the New Testament. Christ is the same as God. There is

9 no other Christ. God became man in Jesus Christ to preach the gospel to humans. He went to the earth of 10 the dead to preached the gospel 3 days in the death world, returned to the earth, and then to the heaven.

11 This is the spiritual journey. Emmanuel is God with us. The mathematical model of Christ is - $\leq \mathrm{X} \leq \sim$ 12 and $\mathrm{X}=\mathrm{Y}$. A Christian could catch up into paradise as Paul's vision. It was from the earth. It was not 13 from heaven. It is different with Jesus Christ's journey. Christ from heaven down to earth, going to the world of the dead, returning to earth and returning to heaven. Paul's vision shows that the man catch up from the world to heaven, returned to the earth and died. He needed to wait the advent of Christ to rise up him from the death. Christ is eternal forever. The man is not yet $100 \%$ eternal. He still needs to be rise by Christ in the day of the Lord. Satan was from heaven and was thrown into the earth. It was not a spiritual journey. Satan, his angels and the false prophet have been thrown into the hell. The mathematical model of the false prophet is $-\sim \leq \mathrm{X}<\sim$ and $\mathrm{X}=\mathrm{Y}$. The spiritual journey of Jesus Christ is Scholar.

\section{Introduction}

God is the supreme and eternal being who created and preserve all things. He is both transcendent and immanent. Transcendent means wholly independent and beyond the material universe. Immanent means to be involved in the world [1]. Christian teachings of the immanance and involvement of God and his love for humanity exclude the belief that God is the same substance as the creator universe. God's divine Nature unites to human nature in the person of Jesus Christ; that is, the incarnation [2]. Dead in man and return to heaven. It is a spiritual journey from the heaven to the globe and the death, and then returned to the heaven through the world.

The gospel does not introduce a new Lord to replace God as the Lord. The early Christian remained to obey to the Lord in the Old Testament. There is no replacement God with another God. There is one Lord only; that is, Christ, God.

1 Cor. $10: 4$ And did all drink the same spiritual drink: for they drink of that spiritual Rock that followed them: and that Rock was Christ.

Heb. 11 24-26

24 By faith Moses, when he was come to years, refused to be called the son of Pharaoh's daughter;

25 Choosing rather to suffer affiction with the people of God, then to enjoy the pleasures of sin for a reason;

4026 Esteeming the reproach of Christ greater riches than the treasures in Egypt: for he had respect unto the 41 recompence of the reward. 
1 Cor. $10: 4$ and Heb. $11: 26$ show that Rock (God) was Christ and Moses obeyed Christ. It shows that God, who led Israel from Egypt to Canaan, was Christ, too. Therefore, it can be stated that there is no Lord except God, Christ. Jesus said unto them, Verily, verily, I say unto you, Before Abraham was, I am (John $8: 58$ ). Do not be puzzled with this statement.

Abram was the first who knew regarding the advent of Jesus Christ on this globe. God notified directly the advent of Christ to Abraham. God stated that Abraham seed bless all the nations of the earth. Then, God notified to others such as Moses, David and Daniel regarding the advent of Christ. Jesus Christ is the son of God and the son of Man. As the Son of man, he spent his life on the globe as commonly humans. He went to the death, but as Christ quickened by the Spirit, God. Jesus Christ was about 33 years on the globe. He preached the gospel around 3 years to humans. Jesus Christ went to the dead world to preach the gospel around 3 days. He returned to the world 40 days and then returned to the heaven. This is the spiritual journey to preach the gospel to all creatures. Jesus Christ's disciples will follow his journey from the world of the dead to heaven in the day of the Lord. These people will go the heaven with Christian people that alive at that time.

\section{God and the Lord}

The Old Testament usually uses the name of God in singular such as Ex. $20: 17$ and Ps. $8: 1$. It generally uses the terms in a very general sense rather than referring to any special designation of God. The general name of God may include other special names. These names express his multifaceted attributes [3].

God was the creator of the heavens and the earth. Commonly, some names for God exist in the Bible. These include the following: God, the Lord God, and the Lord. There are also other names such as Almighty and the Spirit of God (Job $33: 4$ ), Almighty God (Gen. 17:1), God of Israel (Ex. $24: 10)$. God is the same as the Lord God and the Lord. There is no Lord except God, the Lord God. I am the Lord; and there is none else (Isa. 45 : 18). There is only one God; that is, God, the Lord God, and the Lord (Table 1).

The names of the Father, Son and the Holy Spirit correspond to the New Testament such as at the end of the Gospel of Matthew $(28: 19)$. This verse states make disciples the entire nation, baptizing them into the name of the Father and of the Son and of the Holy Spirit [4]. It suggests that God includes the Spirit, Christ and Son of Man. God is not the flesh.

God everlastingly arises from the Father and the Son. He joins the Father and the Son in everlasting love. He is the Spirit [1]. God is the Spirit, Life, Truth, and Supreme Being. God is the source of life. It is according to the first of Genesis that God created man, animal, plant, and others. The Spirit of God could move upon the face of the waters (Gen. 1:2), be with man (Gen. $6: 3$ and I Sam. 16:14), for example. He created and gave a living soul to man (Gen. $1: 26-27$, Gen $2: 7$ and Job33 : 4). He is both distance and close (Jer. $23: 23-24)$. He could in the heaven and the hell (Ps. 139:8). God drives the heavens and the hell. It shows that God is life and the source of live for all creatures. God could be everything such as man, the burned bush, and angel. He is everywhere. Emmanuel, which being interpreted is, God with us (Matt. $1: 23$ ). The Spirit itself beareth witness our spirit, that we are the children of God (Rom. $8: 16$ ). Remember that the Spirit is separated with our spirit. There is God everywhere.

As the Supreme Being, God can do everything. For example, God could be a flame of fire out the midst of a bush as an angel (Ex. $3: 2$ ), and then as God (Ex. $3: 4$ - 7). It seems that God before speaking with Moses sent his angel as the bush burned with fire but not consumed, and then God replaced the angel. If God could be an angel, of course, he could also be a man, Jesus Christ. The Lord went before Israel by the day in a pillar of a cloud and by night in a pillar of fire (Ex. $13: 21)$. It is also stated that pillar of a cloud or of fire was an angel (Ex. $14: 19$ ). Say that God fills the universe, and then God could send an angel in a place in the universe. If there is a building in the universe, then God could send an angel to fill 
the building. In addition, the building could be God itself since God can replace an angel as God. God has power to do it. A bush is a part of the universe that God could replace as itself. The burned bush saw could be an angel or God. Thus, Jesus Christ, who is the Spirit of God within him, is God, the Lord. It is the truth to state that Christ Jesus is the Lord and there is no Lord except God or Christ. This is the true God, and eternal life (1 John $5: 20$ ).

God is Spirit. The Spirit is different from the flesh. The flesh, among other things, is absolutely, uncleanness, fornication, and lasciviousness (Gal. 5 : 19). The Spirit is love, joy, peace, gentleness, goodness, long suffering, goodness, faith (Gal. $5: 22$ ). Love in God is kind and rejoiced in the truth (1 Cor. 13 : 4-7). No man could see God (Ex. 33 : 20), God face in particular (Ex. 33 : 23). However, God back parts could be seen by man (Ex. $33: 23$ ). Therefore, in the era of early Christian, man, particularly his disciples, could not see Christ face within Jesus Christ. They could see God in Jesus Christ as the back parts of God only. Man could touch the body of Jesus Christ even put him in the cross. However, no one could touch the Spirit of Christ within Jesus Christ. It seems that God gives the opportunity to see God (1 Cor. $2: 9)$, not the face within Christ, for man who loves God. God has revealed himself within Jesus Christ unto the children of God by the Spirit: for the Spirit searcheth all things, yea the deep thing of God (1 Cor. 2 : 10). God is love, joy, pure, etc. Therefore, God is the truth.

\section{Christ}

Jesus Christ is Son of God [5]. The scripture indicates that there is one God, the Father, and one Lord Jesus Christ (1 Cor. $8: 6$ ). There is none other God (1 Cor. $8: 4)$ ). Jesus Christ was conceived in his mother was of the Holy Ghost (Matt. $1: 20$ ). The Holy Ghost, the Spirit is in Jesus Christ (Matt. $3: 16$, Mark $1: 10$, Luke $3: 22$, and John $1: 32$ ). The Father, God created everything. Man's life is for God, the Spirit, and Holy Ghost. The children of God know about God through Jesus Christ, the Lord. He is the Son of God, the Lord. It is reasonable to state that Christ, the Spirit, created all things. There is none other Lord except Jesus Christ, God. God is the same as Christ.

According to the Bible, the coming of Christ is indicated as follows: God made covenant Abram (Abraham) and his seed for an everlasting covenant as their God (Gen. 17 :7), the Almighty God (Gen. 17 : 1). Isaac was the son of Abraham and God had made a covenant with Isaac as an everlasting covenant, too (Gen. 17 : 19). Moses stated that God would raise a prophet for Israel and they should hear the prophet (Deut. $18:$ 15). God, who was through Nathan, stated that God will set up David's generation and shall proceed up of bowels, and will establish his kingdom. God will establish the throne of his kingdom forever, and will be his father and he will the son (II Sam. $7: 12$-14). Jesus is the son of David. The book of the generation of Jesus Christ, the son of David, the son of Abraham (Matt. 1:1) can be seen in Matt. $1: 1-17$ and Luke $3: 23-38$. The pedigree describes generation from both Joseph and Mary.

To answer the high priest, Jesus stated clearly that he was the Christ, the Son of the Blessed (Mark 14 : 61-62). Jesus has power to conduct items such as miracles and healings. More important, Christ can resurrect the dead people and resurrected from the death. His miracles related to the Spirit, not the flesh or natural man. The natural man can do "miracles" that related to mortality only. They only can make a good item such as book, house and monument for instance. Man in the flesh could destroy a bible. However, the flesh cannot destroy life in the Spirit! Jesus provides the way to life in the Spirit. The Spirit is immortal. Natural man is mortal. Jesus Christ is the Lord.

Around two thousand years ago, Christ did a journey from the paradise to the earth around thirty-three years, to the death for preaching the spirits in prison, and back to the earth for his disciples and others, and then to paradise. He stated to his enemies that he was from above, the kingdom of God; they were from beneath, the death. To indicate that he was from above, he made miracles and healings. He preached the gospel for around three years. After that period, he went to the dead people world to 
preach the gospel to them for three days. He resurrected from the death. Forty days later, he went to paradise (Figure 1). Only God can do such journey. It is Christ.

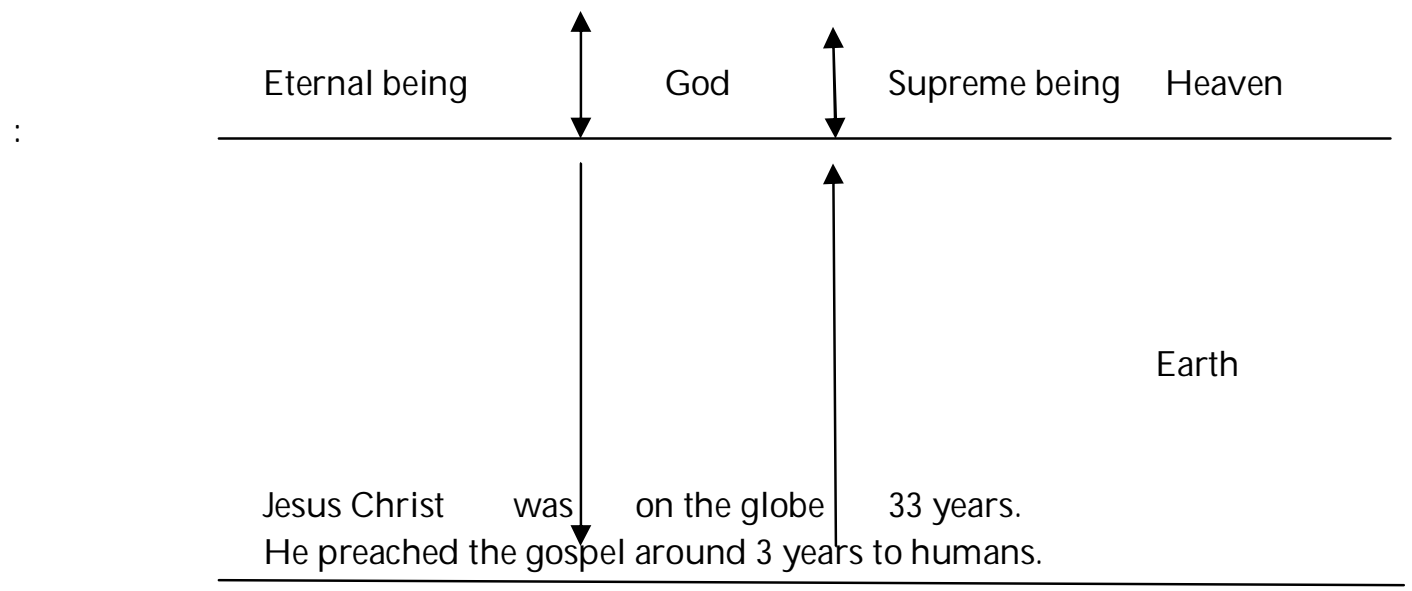

He preached the gospel to the spirits $4 \mathrm{n}$ the dead world. Earth of the dead He was 3 days in thedeath and quickened by the Spirit.

Figure 1. This is the spiritual journey of Jesus Christ. God became man, dead in Jesus Christ, returned to heaven through the globe.

Jesus Christ brought the original gospel to the world. He taught the genuine gospel to his disciples. Only Christ can do this job. Man even Moses, David, for instance, could not do the job. To do this job, Christ should be in a man form. It is a process. It is impossible if God directly teach the genuine gospel to human. He should be in Jesus. When leading Israeli from Egypt to Palestine, Christ is in a pillar of a cloud or of a fire. In the New Testament, Christ leads the disciples in Jesus Christ. Christ cannot be seen by the disciples but they could see Jesus as a pillar of a cloud in the Moses time (Old Testament). After teaching the genuine gospel to the world of the dead, Jesus Christ strengthened by the Spirit went back to the world, and then to heaven along with the genuine gospel. Thus, the genuine gospel is in heaven now along with Christ. This is the scholar event! For example, Christ in the mathematical model is as $-\sim \leq \mathrm{X} \leq \sim$ and the false is as $-\sim \leq \mathrm{X}<\sim ; \mathrm{X}=\mathrm{Y}$. These models are ideas. Thus, Christ fills the entire universe, while the false not $(<\sim)$ ! The Christ is in the paradise $(\leq \sim)$, while the false cannot reach the paradise!

\section{Son of Man}

According to the Bible, God creates the spiritual man after his image and likeness. It is the truth. However, it is not the truth that God created the natural man according to his image and likeness as Satan and his seed opinion. It is heresy. There is no likeness between God, the Spirit or the Holy Ghost, and Satan or the natural man. God, Christ, spiritual man is from above, heaven. Satan and natural man or the flesh is from beneath. The first man, Adam, was spiritual man. Both Adam and Eve did not contaminate by $\sin$ before Satan succeeded tempting Eve and then Adam. After falling in sin, Adam and Eve were natural man. Christ went to this globe saving humans from Satan and his followers.

Jesus taught to his disciples that he, as the Son of man, must suffer many things, and be rejected of the elders, and of the chief priests, and scribes, and be killed, and after three days rise again (Mark 8 : 
31). He had seen all things that he would face and had power to know these items. He told everything to the disciples. He is Christ, the Lord, and God.

God could be everywhere at the same time in both heaven and hell. If I ascend up into heaven, thou art there: if I made my bed in hell, behold, thou art there (Psalm 139: 8). The Spirit, who raised Jesus Christ from the death, is the same as God, Christ. Jesus put to death in the flesh, but quickened by the Spirit: By which also he went and preached unto the spirits in prison (1 Pet. $3: 18$ and 19), and then rose up after three days along with the spirits in the death.

It could be stated Jesus died for three days. There was a darkness as long as three hours at that time (Mark 15 : 33). It was dark, something as moonless night. A day was divided into two days since it was separated by darkness. Jesus raised up when the Sabbath was past (Mark 16:1). It was three days after he passed away.

Christ showed us around two thousand years ago about how the children of God would/will go to the death and preach the spirits. The spiritual man will preach the gospel to the spirits, too. The beggar named Lazarus into Abraham's bosom did it (Luke $16: 20$ ) as an example for us. The spiritual man into Abraham's bosom will do as Lazarus did, as evidence that the gospel is right.

The spiritual journey of Jesus Christ is different from a Christian who catches up to heaven in Paul's vision (II Cor. 12 : 1-4). The person has seen paradise, but as a human, he certainly died and was buried in the earth. This person is still waiting to be risen by the Lord in the day of the Lord (I Tess $4: 16$ 17). Christ came from the heaven, descended into the earth, died, raised up in the third day, and returned to the heaven (Mark $16: 19$ ) forty days later. Satan was from heaven. He and his angels were cast out into the earth (Rev. $12: 9$ ). The devil and the false prophet have been cast into the lake of fire and brimstone (Rev. $20: 10$ ).

\section{Conclusion}

Christ is the same as God. There is no Lord except God. As a man, Jesus Christ must die. After three days preached the genuine gospel to the death, he came back to earth and then to heaven along with the genuine gospel. The genuine gospel is in the paradise now. Spiritual man, as the son of God, should follow Jesus Christ ways. Go to the world of the dead to preach the gospel to the spirits, and, of course, follow Christ to the heaven. Satan, his angels and the false prophet has been thrown into the hell forever. The history of Jesus Christ is scholar.

Acknowledgements: The author has role in designing of the study and writing of the manuscript.

Author contributions: M.L.N. designed the study, performed the literature searched, wrote the first draft of the manuscript in involved in revising the manuscript critically for significant intellectual need. The author read and approved the final manuscript.

Conflicts of interest: The author declares no conflict of interest.

\section{References}

1. Leith JH. Basic Christian Doctrine. Jan. 1, 1992, pages 55-56. Available from: https:/books.google.com books?isbn=0664251927.

2. Erickson MJ. Introduction to Christian Doctrine. Second edition. April 2001. Available from: https:/books.google.com books?isbn=0801022509.

3. Berkhof L. Manual of Christian Doctrine. August 1, 2007, pages 19-20.

4. Moulasion JB. Lord, giver of life. 2014, page 5. 
5. International Standard Bible. Encyclopedia: Sons of God (New Testament). 2014. BibleStudyTools.com.

1 Cor $8: 5-6$

5 For though there be that are called gods, whether in heaven or in earth, (as there be gods many, and lords many).

Rom 9: 5

Whose are the fathers, and of whom as concerning the flesh Christ came, who is over all, God blessed for ever. Amen.

John $8: 58$

Jesus said unto them, Verily, verily, I say unto you, Before Abraham was, I am.

And we know that the Son of God is come, and hath given us an understanding, that we may know him that is true, even in his Son Jesus Christ. This is the true God, and eternal life.

19 For the Son of God, Jesus Christ, who was preached among you by us, even by me and Silvanus and Timotheus, was not yea and nay, but in him was yea.

20 For all the promises of God in him are yea, and in him Amen, unto the glory of God by us.

21 Now he which stablisheth us with you in Christ, and hath anointed us, is God; John $3: 16$ not perish, but have everlasting life.

John $4: 24$

God is a spirit: and they that worship him must worship him in spirit and in trust.

Gen $1: 1-2$ of God moved upon the face of the water.

\section{Gen $6: 3$}

And the Lord said, my spirit shall not always strive with man, for that he also is flesh: yet his days shall be an hundred and twenty years.

Judges $11: 9$

Then the Spirit of the Lord came upon Jephtha, and he passed over Gilead, and Manasseh, and passed over Mizpeh of Gilead he passed over unto the children of Ammon.

Isa $45: 18$

For thus said the Lord that created the heavens; God himself that formed the earth and made it; he hath established it not in vain, he formed to be inhabited: I am the Lord; and there is none else.

Isa $63: 14$

As a beast goeth down into the valley, the Spirit of the Lord caused him to rest: so didst thou lead thy people, to make thyself a glorious name.

260 And ye my flock, the flock of my pasture, are men, and I am your God, saith the Lord God.

261 Phil 2:11 
And that every tongue should confess that Jesus Christ is Lord, to the glory of God the Father.

2632 Cor $3: 17$

264 Now the Lord is that Spirit: and where the Spirit of the Lord is, there is liberty.

2651 Thess 1

266 Paul, and Silvanus, and Timotheus, unto the church of the Thessalonians which is in God the Father and in the Lord Jesus Christ: Grace be unto you, and peace, from God our Father, and the Lord Jesus Christ. Mark $14: 61-62$

61 But he held his peace, and answered nothing. Again the high priest asked him, and said unto him, Art though the Christ, the Son of the blessed?

62 And Jesus said, I am: and ye shall see the Son of man sitting on the right hand of power, and coming in the clouds of heaven.

Mark $1: 10-11$

10 And straightway coming up out of the water, he saw the heavens opened, and the Spirit like a dove descending upon him:

11 And there came a voice from heaven, saying, Thou art my beloveth Son, in whom I am well pleased.

I will declare the decree: the Lord hath said unto me, Thou art my Son; this day have I begotten thee.

Isa $42: 1$

BEHOLD my servant, whom I uphold; mine elect, in whom my soul delighted; I have put my spirit upon him: he shall bring forth judgment to the Gentiles.

Mark $9: 7$

And there was a cloud that overshadowed them: and a voice came out of the cloud, saying, This is my beloved Son: hear him.

John $14: 6$

Jesus said unto him, I am the way, the truth, and the life: no man cometh unto the Father, but by me.

Rom $1: 4$

And declared to be the Son of God with power, according to the spirit of holiness, by the resurrection from the dead:

Acts $4: 12$ Neither is there salvation in any other: for there is none other name under heaven given among men, whereby we must be saved.

Phil $2: 5-8$

5 Let this mind be in you, which was also in Christ Jesus:

6 Who, being in the form of God, though it not robbery to be equal with God:

7 But made himself of no reputation, and took upon him the form of a servant, and was made in the likeness of men:

8 And being found in fashion as a man, he humbled himself, and became obedient, even the death of the cross.

Jer $23: 23-24$

$23 \mathrm{Am}$ I a God at hand, said the Lord, and not a God afar off?

24 Can any hide himself in secret places that I shall not see him? Said the Lord. Do not I fill heaven and earth? Said the Lord.

Ps $23: 4$

Yea, though I walk through the valley of the shadow of death, I will fear no evil: for thou art with me; thy rod and thy staff they comfort me.

Ps $139: 8$

If I ascend up into heaven, thou art there: if I make my bed in hell, behold, thou art there.

Mark $15: 33-41,46-47$

33And when the sixth hour was come, there was darkness over the whole land until the ninth hour. 
34 And at the ninth Jesus cried with a loud voice, saying, ELOI, ELOI, LAMA SABACHTHANI? Which is, being interpreted, My God, my God, why hast thou forsaken me?

36 And one ran and filled a spunge full of vinager, and put it on a reed, and gave him to drink, saying, Let alone; let us see whether Elias will come to take him down. 37 And Jesus cried with a loud voice, and gave up the ghost.

38 And the veil of the temple was rent in twain from the top to the bottom.

39 And when the centurion, which stood over against him, saw that he so cried out, and gave up the ghost, he said, Truly this man was the Son of God.

40 There were also women looking on a far off: among whom was Mary Magdalene, and Mary the mother of James the less and of Joses, and Salome;

41 (Who also, when he was in Galilee, followed him, and ministered unto him;) and many other women which came up with him unto Jerusalem.

46 And he bought fine linen, and took him down, and wrapped him in the linen, and laid him in a sepulcher which was hewn out of a rock, and rolled a stone unto the door of the sepulcher.

Acts $3: 18$ But those things, which God before had shewed by the mouth of all his prophets, that Christ should suffer, he heth so fulfilled.

1 Pet $3: 18-20$

18 For Christ also hath once suffered for sins, the just for the unjust, that he might bring us to God, being put to death in the flesh, but quickened by the Spirit:

19 By which also he went and preached unto the spirits in prison:

20 Which sometime were disobedient, when once the longsuffering of God waited in the days of Noah, while the ark was a preparing, wherein few, that is, eight souls were saved by water.

Mark $16: 6-7$

6 And he said unto them, Be not affrighted: Ye seek Jesus of Nazareth, which was crucified: he is risen: he is not here: behold the place where they laid him.

Rom $14: 9$

For to this end Christ both died, and rose, and revived, that he might be Lord both of the dead and living. 1 Cor $15: 3-9$

3 For I delivered unto you first of all that which I also received, how that Christ died for our sins according to the scriptures;

4 And that he was buried and that he rose again the third day according to the scriptures:

5 And that he was seen of Cephas, then the twelve:

6 After that, he was seen of above five hundred brethren at once; of whom the greater part remain unto this present, but some are fallen asleep.

7 After that, he was seen of James; then of all the apostles.

8 And last of all he was seen of me also, as of one born out of due time.

9 For I am the least of the apostle, that am not meet to be called an apostle, because I persecuted the church of God.

Mark $16: 19$

So then after the Lord had spoken unto them, he was received up into heaven, and sat on the right hand of God.

Acts $1: 9-11$

9 And when he had spoken these things, while they beheld, he was taken up; and a loud received him out of their sight.

10 And while they looked steadfastly toward heaven as he went up, behold, two men stood by them in white apparel; 
35711 Which also said, Ye men of Galilee, why stand ye gazing up into heaven? This same Jesus, which is 358 taken up from you into heaven, shall so come in like manner as ye have seen him go into heaven.

359 Eph $4: 8-10$

3608 Wherefore he saith, When he ascended up on high, he led captivity captive, and gave gifts unto men.

3619 (Now that he ascended, what is it but he also descended first into the lower parts of the earth?

$36210 \mathrm{He}$ that descended is the same also that ascended up far above all heavens, that he might fill all 363 things.)

364

365 Verses correspond to the spiritual journey of Jesus Christ could be searched using the internet. There is 366 much software for free that could be downloaded for that purpose. 